\title{
An airborne regional carbon balance for Central Amazonia
}

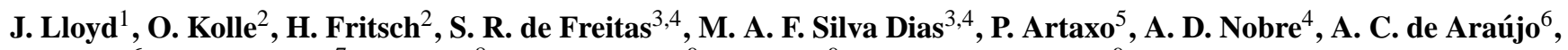 \\ B. Kruijt ${ }^{6}$, L. Sogacheva ${ }^{7}$, G. Fisch ${ }^{8}$, A. Thielmann ${ }^{9}$, U. Kuhn ${ }^{9}$, and M. O. Andreae ${ }^{9}$ \\ ${ }^{1}$ Earth and Biosphere Institute, School of Geography, University of Leeds, Leeds, LS2 9JT, UK \\ ${ }^{2}$ Max-Planck-Institut für Biogeochemie, P.O. Box 100164, 07701 Jena, Germany \\ ${ }^{3}$ Departamento de Ciências Atmosféricas, Instituto de Astronomia Geofísica e Ciências Atmosféricas, Univ. de São Paulo, \\ Rua do Matão, 1226, 05508-900, São Paulo, SP, Brazil \\ ${ }^{4}$ Centro de Previsão do Tempo e Estudos Climaticos, Inst. Nacional de Pesquisas Espaciais, Rodovia Presidente Dutra, Km \\ 40, SP-RJ, 12630-000, Cachoeira Paulista, SP, Brazil \\ ${ }^{5}$ Instituto de Física, Universidade de São Paulo, Rua do Matão, Travessa R, 187, Cidade Universitária, 05508-900, São \\ Paulo,SP, Brazil \\ ${ }^{6}$ Wageningen Univ. and Res. Centre, P.O. Box 47, 6700 AA Wageningen, The Netherlands \\ ${ }^{7}$ Department of Physical Sciences, P.O. Box 64, 00014 University of Helsinki, Finland \\ ${ }^{8}$ Centro Técnico Aeroespacial (CTA), Praça Marechal Eduardo Gomes, 50, CEP 12228-904, São José dos Campos, SP, Brazil \\ ${ }^{9}$ Max-Planck-Institut für Chemie, P.O. Box 3060, 55020 Mainz, Germany
}

Received: 7 December 2006 - Published in Biogeosciences Discuss.: 24 January 2007

Revised: 24 July 2007 - Accepted: 2 September 2007 - Published: 14 September 2007

\begin{abstract}
We obtained regional estimates of surface $\mathrm{CO}_{2}$ exchange rates using atmospheric boundary layer budgeting techniques above tropical forest near Manaus, Brazil. Comparisons were made with simultaneous measurements from two eddy covariance towers below. Although there was good agreement for daytime measurements, large differences emerged for integrating periods dominated by the night-time fluxes. These results suggest that a systematic underestimation of night time respiratory effluxes may be responsible for the high Amazonian carbon sink suggested by several previous eddy covariance studies. Large $\mathrm{CO}_{2}$ fluxes from riverine sources or high respiratory losses from recently disturbed forests do not need to be invoked in order to balance the carbon budget of the Amazon. Our results do not, however, discount some contribution of these processes to the overall Amazon carbon budget.
\end{abstract}

\section{Introduction}

The carbon balance of the Amazon is a matter of ongoing debate. Early observational and theoretical work suggested a relatively small carbon sink of order $10 \mathrm{~mol} \mathrm{C} \mathrm{m}^{-2} \mathrm{a}^{-1}$ (Grace et al., 1995a; Lloyd, 1999) and this is also broadly consistent with well documented increases in rates of above ground biomass inventory accumulation (Phillips et al., 1998; Baker et al., 2004). Some eddy covariance measure-

Correspondence to: J. Lloyd

(j.lloyd@leeds.ac.uk) ments have, however, suggested much larger estimates for tropical forest carbon sequestration in the Amazon Basin - in the range 40-60 $\mathrm{mol} \mathrm{C} \mathrm{m}^{-2} \mathrm{a}^{-1}$ (Malhi et al., 1998; Araújo et al., 2002; Carswell et al., 2002). Recently, Saleska et al. (2003) have argued that these eddy covariance studies (as well as the earlier study of Grace et al., 1995a) overestimated the carbon sink of the studied stands due to a failure to account for flux "losses" resulting from periods of low turbulence at night. They also suggested that tropical forests suffer from intermittent disturbances which may give rise to episodic large carbon losses; this also causing a simple extrapolation of stand-level measurements above relatively undisturbed forests to give erroneous regional carbon balances. This criticism was extended to the interpretation of results from the above ground inventory work of Phillips and colleagues (Phillips et al., 1998; Baker et al., 2004).

That the Amazon may be more or less in carbon balance was also suggested by Chou et al. (2002), who reanalyzed the results of the 1987 ABLE-2 experiment (Wofsy et al., 1988) to obtain regional flux estimates for an undefined region NW of Manaus in the central Amazon. They suggested a more or less neutral carbon balance that could best be explained by a substantial $\mathrm{CO}_{2}$ efflux from rivers and wetlands. They suggested that, although intact forest may have been accumulating carbon at the time, this was being offset by a significant efflux of $\mathrm{CO}_{2}$ from riverine sources at a regional scale. This notion has been supported in general by direct measurements and calculations of wetland and river $\mathrm{CO}_{2}$ evasion rates by Richey et al. (2002).

Published by Copernicus Publications on behalf of the European Geosciences Union. 
Table 1. Details for all 14 flight undertaken, showing the local times of the measurement spirals (UST - 4h) as well as trajectory codes (supplementary information: http://www.biogeosciences.net/4/759/2007/bg-4-759-2007-supplement.pdf), and the day or night time integral period(s) to which the flights relate.

\begin{tabular}{|c|c|c|c|c|c|}
\hline Flight No & Start Spiral & End Spiral & Trajectory & Day "Period" & "Night Period" \\
\hline Claire-II-3 & 07/07/2001 10:08 & 07/07/2001 10:28 & & & \\
\hline Claire-II-4 & 07/07/2001 16:06 & 07/07/2001 16:23 & 07072030 & & \\
\hline Claire-III-5 & 08/07/2001 09:27 & 08/07/2001 09:45 & 07081330 & & \\
\hline Claire-II-6 & 10/07/2001 15:43 & 10/07/2001 16:19 & Not made & & \\
\hline Claire-II-7 & 11/07/2001 09:34 & 11/07/2001 09:51 & Not made & & \\
\hline Claire-II-8 & $11 / 07 / 2001$ 15:37 & $11 / 07 / 2001$ 15:54 & Figure 1 & & \\
\hline Claire-III-9 & 12/07/2001 09:23 & 12/07/2001 09:42 & Figure 1 & & \\
\hline Claire-II-13 & $16 / 07 / 2001$ 15:58 & 16/07/2001 16:13 & 07162000 & & \\
\hline Claire-II-14 & 17/07/2001 09:43 & 17/07/2001 10:02 & 07171400 & & \\
\hline Claire-II-15 & 17/07/2001 15:18 & $17 / 07 / 200115: 42$ & 07172000 & & \\
\hline Claire-II-16 & 18/07/2001 09:26 & 18/07/2001 09:43 & 07181400 & & \\
\hline Claire-II-17 & 18/07/2001 16:12 & 18/07/2001 16:32 & 07182000 & & \\
\hline Claire-II-20 & 20/07/2001 11:17 & 20/07/2001 11:36 & 07201400 & & \\
\hline Claire-II-21 & 20/07/2001 14:43 & 20/07/2001 15:02 & 07202000 & & \\
\hline
\end{tabular}

To help resolve these questions, we used regional atmospheric boundary layer (ABL) budgeting techniques to assess the regional carbon balance of an area of tropical rainforest located at $2.5^{\circ} \mathrm{S}, 60.2^{\circ} \mathrm{W}$; about $60 \mathrm{~km} \mathrm{NNW}$ of the city of Manaus. We derived regional-scale surface fluxes for both day and night-time periods, and compare our regional carbon budgets to those derived from two eddy covariance towers operating concurrently. We interpret our results in terms of all three recently advanced theories explaining apparent contradictions between the various studies, viz substantial riverine sources of $\mathrm{CO}_{2}$ being present (Richey et al., 2002), problems with night time eddy covariance measurements, and intermittent disturbances not being accounted for in tropical rainforest carbon budgets. (For an overview see Ometto et al., 2005).

\section{Material and methods}

The study area was located within a Biological Reserve of the Instituto Nacional de Pesquisas da Amazônia (INPA), consisting of tropical forest canopy of on average 30 to $40 \mathrm{~m}$ height but with occasional emergent trees to $50 \mathrm{~m}$. The general experimental area has been described in detail elsewhere (Andreae et al., 2002; Araújo et al., 2002).

During the period 7-21 July 2001, profiles of $\mathrm{CO}_{2}$ from $100 \mathrm{~m}$ to $3000 \mathrm{~m}$ above ground level were obtained on 14 occasions. Profiles were typically made either at around 10:00 h Local Time, LT, (morning conditions) or 16:00 h LT (afternoon conditions). Morning flights were timed to coincide with the early period of convective growth, during which respired $\mathrm{CO}_{2}$ trapped within the forest canopy overnight was anticipated to have just been mixed into the growing ABL (Lloyd et al., 1996). Afternoon flights coincided with the time at which the sensible heat flux from the rainforest canopy into the $\mathrm{ABL}$ was approaching zero. In all cases, flights were made between two eddy covariance flux measurement towers ("C14" and "K34") situated about 11 $\mathrm{km}$ from each other. Data from both these towers had previously suggested that the apparently undisturbed rain forest of the region is accumulating carbon at a rate of up to $50 \mathrm{~mol} \mathrm{C} \mathrm{m}^{-2} \mathrm{a}^{-1}$ (Malhi et al., 1998; Araújo et al., 2002). The flight details are given in Table 1.

\subsection{Flight instrumentation}

Measurement flights were conducted as part of the Cooperative LBA Airborne Regional Experiment (LBA-CLAIRE 2001) using a Bandeirante aircraft (Embraer EMB 145) equipped with a system designed for the accurate and continuous profiling of atmospheric $\mathrm{CO}_{2}$ concentrations (Lloyd et al., 2002) using an LICOR 6251 infrared gas analyzer (IRGA). Air flow through the analyzer was at a rate of 1.7 to $2.5 \times 10^{-5} \mathrm{~m}^{3} \mathrm{~s}^{-1}$, depending on the ambient pressure. The pressure of the IRGA cell was continuously monitored using a Vaisala PTB 100A pressure transmitter connected via a polyurethane tube to the output port of the sample cell. The analogue Vaisala output was passed back to the LICOR 6251 for pressure corrections according to the customized software. The LICOR pressure corrected $\mathrm{CO}_{2}$ mole fractions and the raw barometer output were logged at $1 \mathrm{~Hz}$ frequency with a Campbell CR21X laptop computer combination. The IRGA was recalibrated regularly during each flight, typically at every $250 \mathrm{~m}$ elevation increments using span gases of 

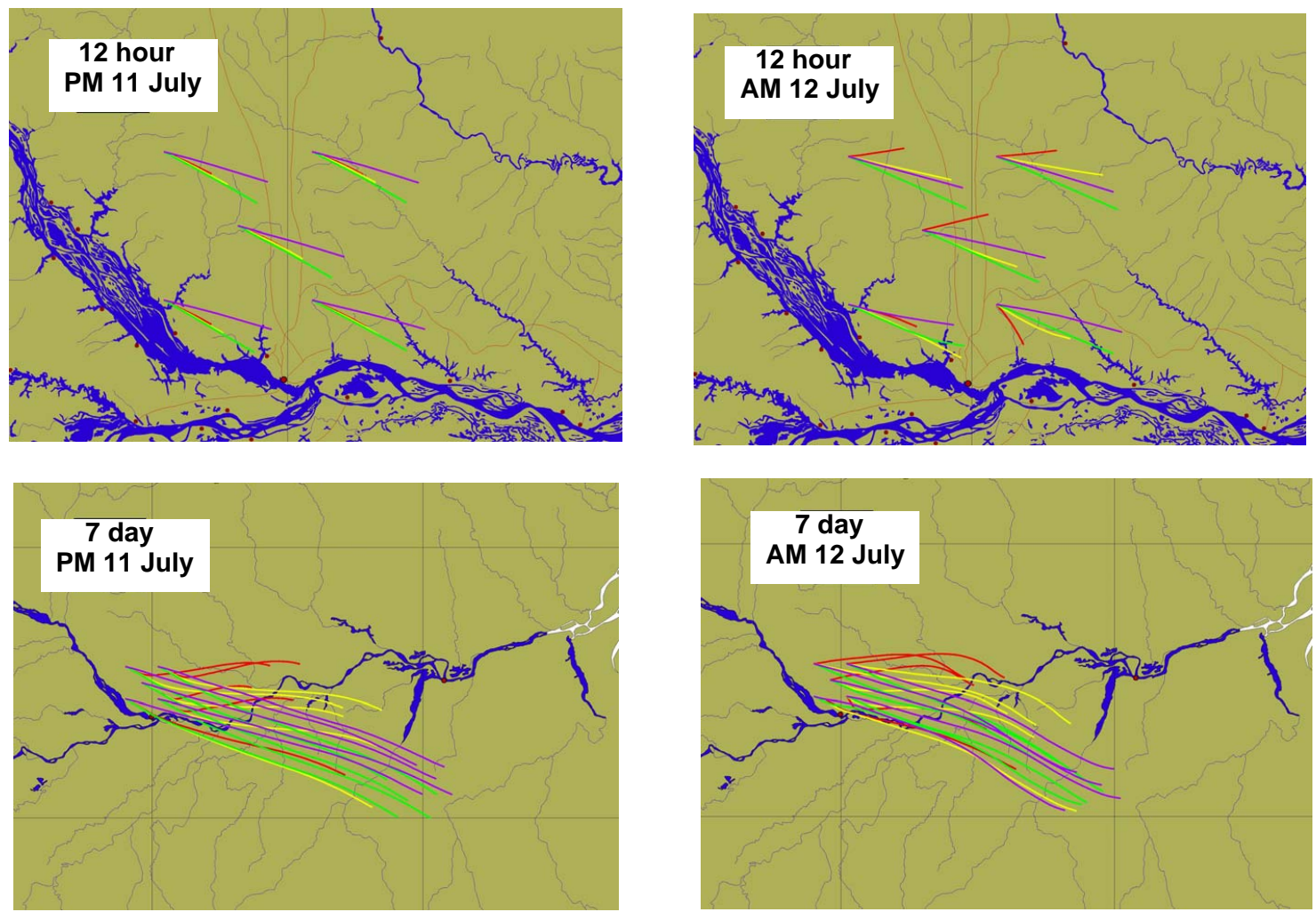

Fig. 1. Twelve hour and 7 day back trajectories for airmasses arriving for the flights of p.m. 11 July and a.m. 12 July 2001 . The following color coding is used: red $-250 \mathrm{~m}$ arrival height; yellow $-750 \mathrm{~m}$ arrival height; green $-1500 \mathrm{~m}$ arrival height; magenta - $3000 \mathrm{~m}$ arrival height. Trajectories are shown not only for the RAMS model grid cell closest to the point of measurement, but also for airmasses arriving at adjacent grid cells. Similar trajectories for a further 9 flights can be found in the supplementary information (http://www.biogeosciences.net/ 4/759/2007/bg-4-759-2007-supplement.pdf).

approximately 340 and $380 \mu \mathrm{mol} \mathrm{mol}^{-1}$. Also connected to the data logger with a $1 \mathrm{~Hz}$ acquisition time was instrumentation to measure humidity and temperature (model HMP35D, Vaisala, Helsinki, Finland), mounted on the port wing close to the gas inlet tubes (directly in the airstream) and a second barometer giving the cabin pressure.

Continuous-profile data were reprocessed off-line to take into account the inability of the IRGA software to correct for changes in atmospheric pressure on the raw output signal. This is presumably due to effects such as band broadening with the changes in pressure, which occur in addition to changes in the density of $\mathrm{CO}_{2}$ molecules in the sample cell. To achieve this, calibration gas values were interpolated between each recalibration measurement (usually every $250 \mathrm{~m}$; see above) as has already been described (Lloyd et al., 2002).

\subsection{Estimates of the regional flux}

The method we applied follows directly Laubach and Fritsch (2002) where one can find a more detailed description of what follows here. Briefly, the surface flux is calculated for a column of fixed air mass as the difference in concentrations of any entity $s$ (in this case $\mathrm{CO}_{2}$ ) at two measurement (flight) times $\left(t_{1}\right.$ and $\left.t_{2}\right)$ according to

$$
\begin{aligned}
\langle R-A\rangle= & \alpha_{s}\left\{M_{\text {top }}\left(\langle s\rangle_{\text {top } 2}-\langle s\rangle_{\text {top } 1}\right)\right. \\
& \left.+\frac{1}{2} w_{\text {top }} \rho_{\text {top }}\left(\Delta s_{1}+\Delta s_{2}\right)\left(t_{2}-t_{1}\right)\right\}
\end{aligned}
$$

where $\alpha_{s}$ is a conversion factor, $R$ is the regional ecosystem respiration rate, $A$ is the regional rate of photosynthetic $\mathrm{CO}_{2}$ assimilation; $\langle R-A\rangle$ thus being the mean surface $\mathrm{CO}_{2} \mathrm{ex}-$ change rate during the integrating period; $M_{\text {top }}$ is the mass per unit surface area at the top of the air column, $w_{\text {top }}$ is the vertical wind velocity at the top of the column, $\rho_{\text {top }}$ is the air density at the top of the column and the $\Delta s$ terms refer to drawdown difference of $s$ at $z=z_{\text {top }}$ where $\mathrm{z}$ is the height above the surface

Within Eq. (1), all the terms on the right hand side can be determined or calculated from aircraft profiles with the exception of $w_{\text {top }}$. Estimates of this term for each integrating period were obtained using vertical velocity estimates from the NCEP/NOAA reanalysis fields (Kalnay et al., 1996), calculated by linear interpolation in height and time. This implies a stepwise (between the layers of the model) constant horizontal divergence of the wind field. 


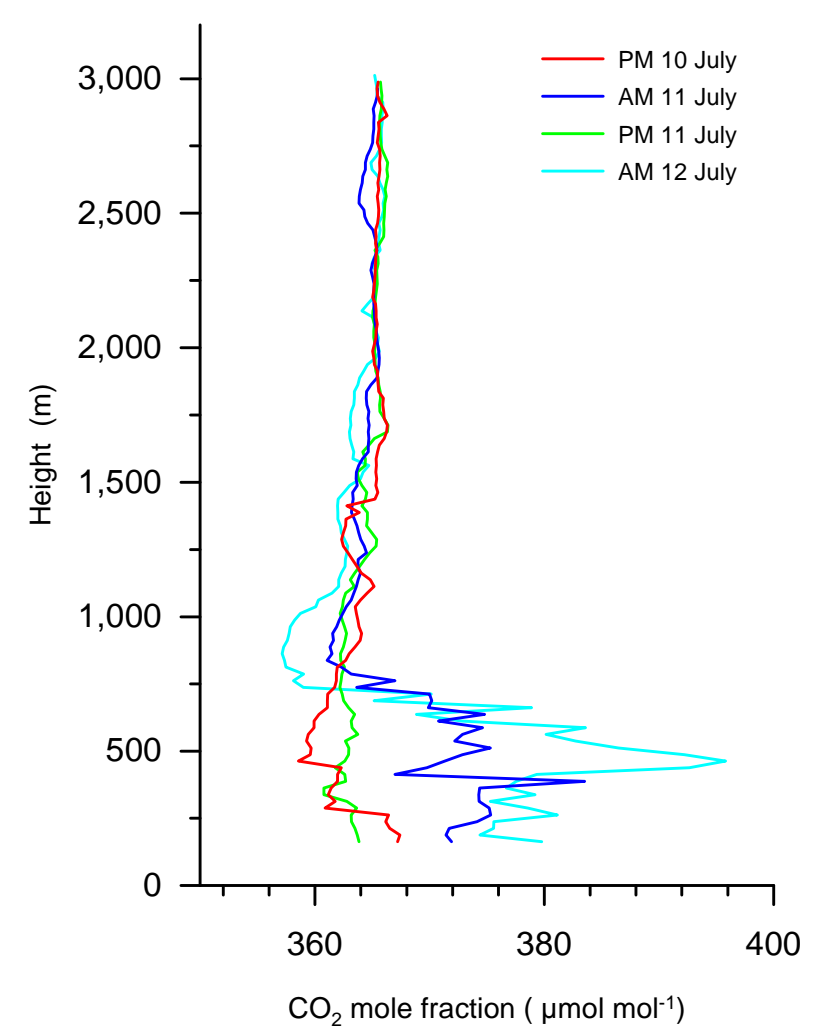

Fig. 2. Vertical $\mathrm{CO}_{2}$ concentration profiles for the late afternoon of 10 July (p.m. 10 July), mid-morning of 11 July (a.m. 11 July), p.m. 11 July and a.m. 12 July. Full flight details can be found in Table 1 .

\subsection{Trajectory analysis and possible advective effects}

To assess the validity of the Eulerian assumptions, and to account for any possible advective fluxes, we employed a convective sigma- $z$ kinematic trajectory technique (Freitas et al., 2000) coupled to the Regional Atmospheric Modeling System (Pielke et al., 1992) at $15 \mathrm{~km}$ resolution. We analyzed 12-h and 7-day back trajectories of air masses arriving for 11 of the measurement flights (heights of origin 250, 750, 1500 and $3000 \mathrm{~m}$ ) with additional input data into the assimilation scheme coming from regular meteorological soundings made between the two towers throughout the flight campaign.

\section{Results}

\subsection{Origin of airmasses}

Trajectories for airmasses arriving at the eddy covariance towers are given in the supplementary information (http://www.biogeosciences.net/4/759/2007/ bg-4-759-2007-supplement.pdf), representative examples of which are shown in Fig. 1. The results for the flights of the evening of 11 July (p.m. 11 July) and morning of 12 July (a.m. 12 July), as for all the other trajectories examined, showed a predominant flow of air into the measurement area from an easterly direction throughout the experimental period. There was also no little vertical variation observed for all trajectories examined suggesting that there had not been any substantial convective mixing of air masses as they transited across the Amazon basin.

\subsection{Vertical profiles}

Representative vertical $\mathrm{CO}_{2}$ profiles, in this case four flights spanning the period p.m. 10 July to a.m. 12 July 2001, are shown in Fig. 2. For the morning flights these profiles, and to a lesser extent in the profiles of potential temperature and water vapour (see Fig. 3), suggest an ABL with a height $(h)$ of about $750 \mathrm{~m}$ on both mornings; and with a substantial accumulation of $\mathrm{CO}_{2}$, presumably respired the previous night, clearly discernable below. Afternoon flights showed the $\mathrm{CO}_{2}$ concentration profiles to have a more uniform vertical structure due to the thermal mixing and (to a lesser extent) mechanical shear (but see Fig. 3).

Temperature and humidity profiles for the p.m. 11 July and a.m 12 July flights are shown in Fig. 3, along with the p.m. 11 July $\mathrm{CO}_{2}$ profiles shown at an expanded scale compared to Fig. 2. This shows the afternoon humidity profile to be complex, with the possible presence of several fossil layers above $h$. Associated fluctuations in humidity relative to mean mixing ratios were anticorrelated to similar variations in $\mathrm{CO}_{2}$ concentration, with an overall $\left[\mathrm{CO}_{2}\right]$ close to the surface depleted on average by about $2 \mu \mathrm{mol} \mathrm{mol}^{-1}$ compared to the free troposphere.

For the morning flight of 12 July, a boundary layer height at about $750 \mathrm{~m}$ is discernable, though mixing within the boundary was still relatively poor as evidenced by the slight positive gradient in potential temperature. Nevertheless, for all flights, especially in conjunction with radiosonde measurements, a boundary layer height could be determined with reasonable certainty and, along with estimates of the vertical velocity above the boundary layer, Eq. (1) applied.

\subsection{Estimation of the regional flux}

From any two successive $\mathrm{CO}_{2}$ profiles (such those in Fig. 2), the regional integrated surface flux for the intervening period can be calculated according to Eq. (1) as the difference between the amount of $\mathrm{CO}_{2}$ contained in the air column at the beginning and end of the period, provided that crucial assumptions are met (see Discussion). There were five overnight periods (ca. 16:00 h to 10:00 h LT) and five daytime periods for which estimates could validly be made (see last two columns of Table 1). Figure 4 shows a comparison between the estimates from the integrated boundary layer budget technique and those from the simultaneously running eddy covariance towers.

This shows that for all daytime measurements the ABL budget method gave values quite similar to the tower-based 

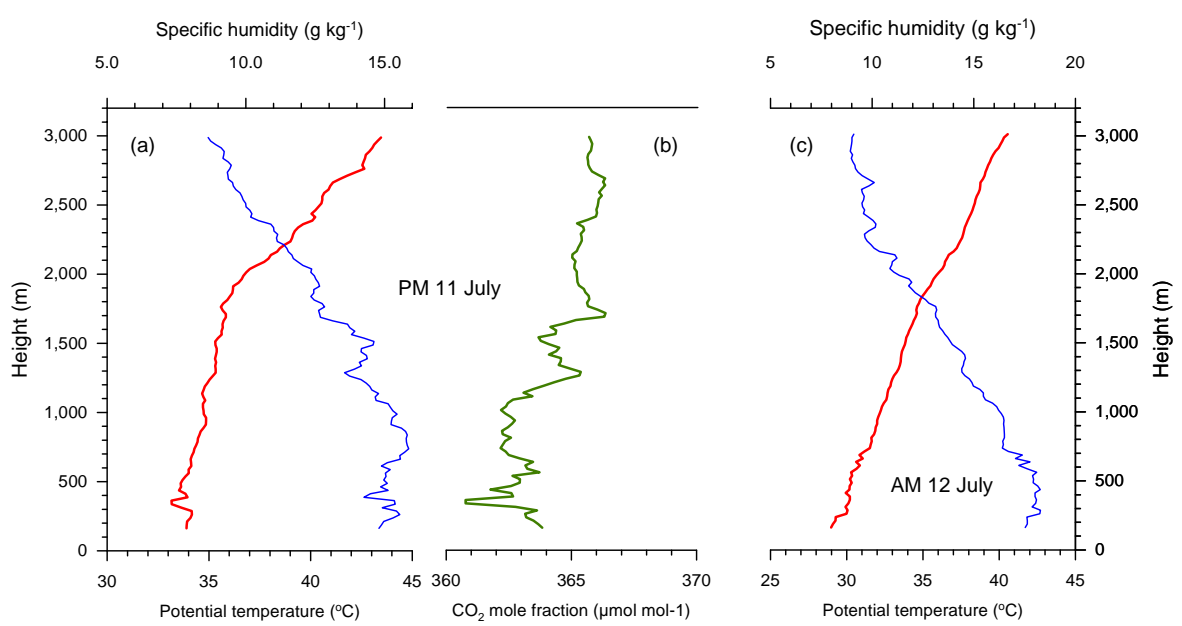

Fig. 3. Vertical profiles of potential temperature and specific humidity for the late afternoon of 11 July (p.m. 11 July) and mid-morning of 12 July (a.m. 12 July). The vertical $\mathrm{CO}_{2}$ profile for the afternoon of $11 \mathrm{July}$ is also shown (expanded scale compared to Fig. 2).

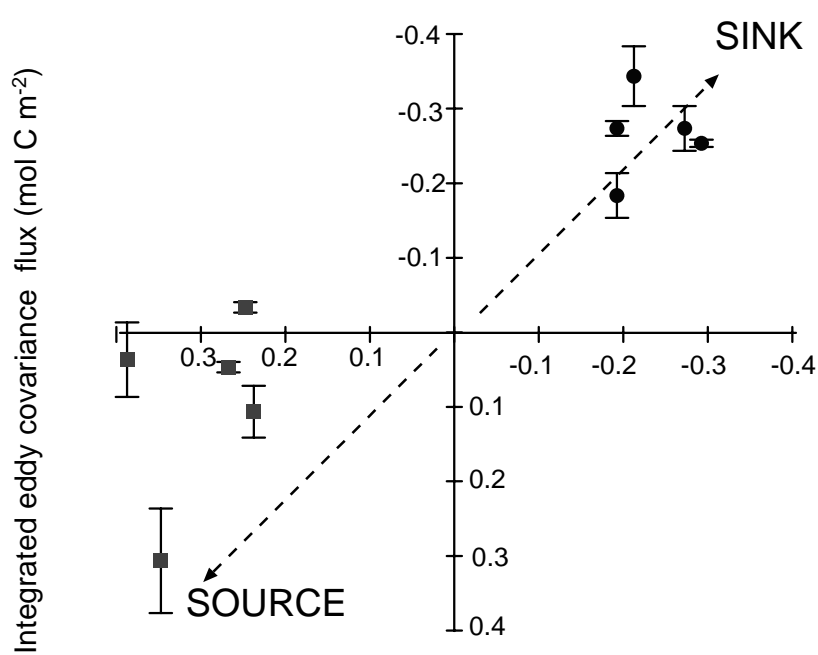

Integrated boundary layer budget flux $\left(\mathrm{mol} \mathrm{C} \mathrm{m}^{-2}\right)$

Fig. 4. A comparison of ecosystem carbon balances using the eddy covariance (mean \pm standard deviation for the two towers) and boundary layer budget method. Typical integration times were $16: 30$ to $10: 30 \mathrm{~h}$ (local time) for "night time" measurements (squares) and 10:30 to 16:30 h for daytime measurements (circles).

flux technique. On the other hand, with only one exception, the eddy covariance method always suggested significantly less net $\mathrm{CO}_{2}$ release for the 16:30-10:30 $\mathrm{h}$ "overnight" period than was indicated by the difference in $\mathrm{CO}_{2}$ content between the evening and morning ABL profiles.

The difference in estimates for the two approaches is shown further in Fig. 5 where fluxes ( 30 min periods) for both towers are shown for the period p.m. 10 July to a.m. 12 July along with the $\mathrm{CO}_{2}$ concentrations as measured at the top of the towers. Figure 5a shows the boundary layer budget es-
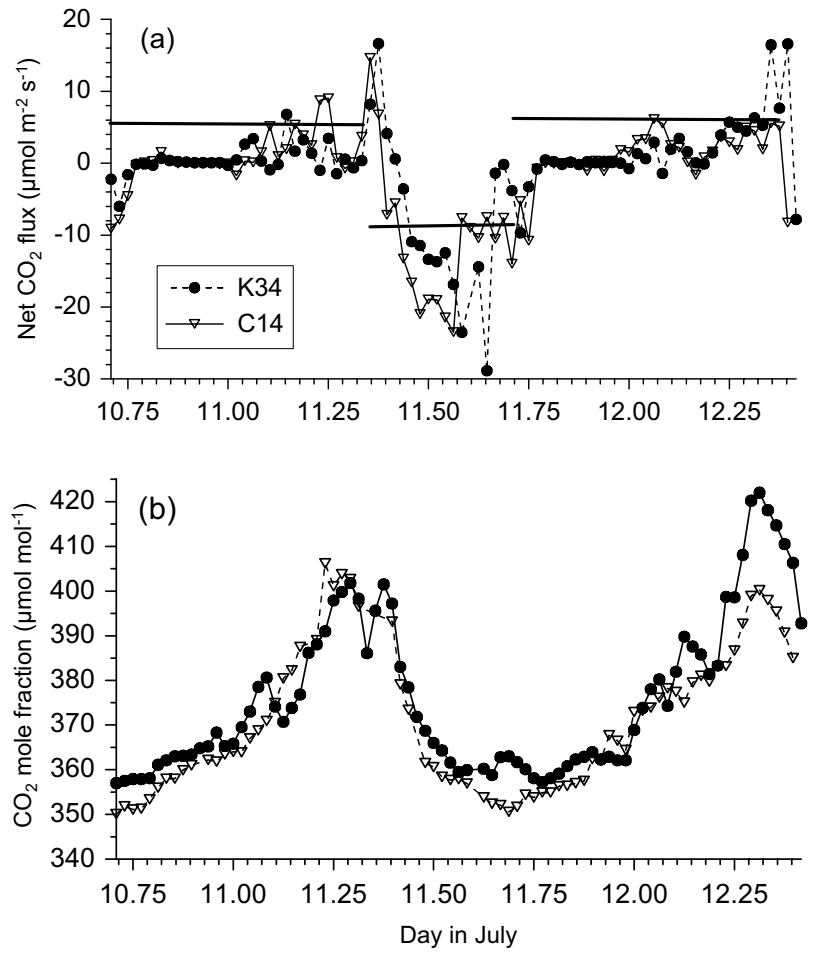

Fig. 5. Pattern of (a) net $\mathrm{CO}_{2}$ flux and (b) $\mathrm{CO}_{2}$ concentrations at the top of the measurement towers from the late afternoon of 10 July till the mid-morning of 12 July. Integrated mean fluxes derived from concurrent airborne $\mathrm{ABL}$ budgeting technique are shown as straight lines in (a).

timates (straight lines), which illustrate that, in contrast to the day time period, significant discrepancies occur at night. Specifically, this shows that the usual close-to-zero flux at the top of the eddy covariance towers during the night-time 
Towers

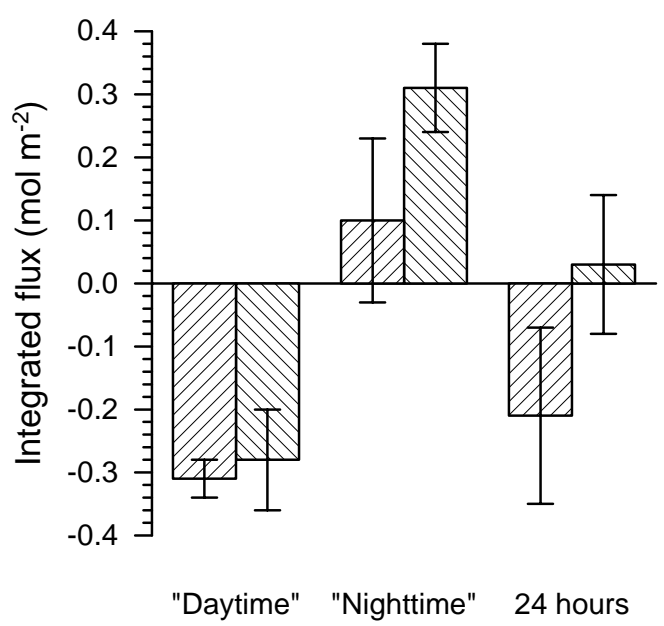

Fig. 6. "Daytime" (typically 16:30 to 10:30 h), "night time" (typically $10: 30$ to $16: 30 \mathrm{~h}$ ) and $24 \mathrm{~h}$ estimate of Central Amazonian rainforest carbon balances compared for the eddy covariance and boundary layer budget method. Error bars represent 95\% confidence intervals.

periods is not sufficiently balanced by a significant large $\mathrm{CO}_{2}$ efflux from the canopy upon the commencement of convective conditions in the early morning to account for the substantially elevated $\mathrm{CO}_{2}$ concentrations observed in the $\mathrm{ABL}$ (Fig. 2). This can be illustrated by simple calculation. From Fig. 2, the average $\left[\mathrm{CO}_{2}\right]$ for the early morning flights is 10 $20 \mu \mathrm{mol} \mathrm{mol}^{-1}$ above that in the evening (averaged over a height of about $750 \mathrm{~m}$ ). Not accounting for any net photosynthetic uptake in the four or so daylight hours before the morning flight, compressing this $\mathrm{CO}_{2}$ into the ca. $50 \mathrm{~m}$ between the ground surface and the eddy covariance measurement systems at the top of the towers would require the average $\left[\mathrm{CO}_{2}\right]$ to be elevated by a factor of $750 / 50 \mathrm{~m}=25$ compared to the ABL; or $250-500 \mu \mathrm{mol} \mathrm{mol}^{-1}$ above the afternoon values. That is to say, the average $\left[\mathrm{CO}_{2}\right]$ from the ground surface to the top of the measurements tower would have to had been $550-800 \mu \mathrm{mol} \mathrm{mol}^{-1}$ just after sunrise, if there were to have been virtually no night-time flux of $\mathrm{CO}_{2}$ out of the canopy as suggested by the eddy covariance measurements. Although concentrations as high as $600 \mu \mathrm{mol} \mathrm{mol}^{-1}$ can occasionally be observed close to the ground surface at night in tropical forests (e.g. Grace et al., 1995b; Kruijt et al., 1996; Lloyd et al., 1996), this has never been observed to be the case for the average value in the canopy space as a whole. We can thus only conclude that, as the night-time eddy covariance flux was almost always close to zero, $\mathrm{CO}_{2}$ either passed the sensor without being detected as a turbulent flux by the eddy covariance system, there was vertical advection, or that there was a lateral flow of $\mathrm{CO}_{2}$ away from the measurement towers during most nights.
The systematic disagreement between the night-time and day-time estimates is shown in Fig. 6, along with the $24 \mathrm{~h}$ mean. This again illustrates the tendency for the two methods to agree for day-time periods but not for night-time periods. It also shows that taken over $24 \mathrm{~h}$ the boundary layer $\mathrm{CO}_{2}$ profiles suggest a net terrestrial carbon balance close to zero. In contrast, the eddy covariance measurements suggested a substantial net uptake of $\mathrm{CO}_{2}$ by the vegetation.

\section{Discussion}

Within this study, we have used ABL budgeting techniques (Wofsy et al., 1989; Raupach et al., 1992; Lloyd et al., 2001; Laubach and Fritsch, 2002) to verify what seemed to be inexplicably high apparent net $\mathrm{CO}_{2}$ uptake rates by tropical forest near Manaus (Malhi et al., 1998; Araújo et al., 2002) - something that was also observed at some other (e.g. Carswell et al., 2002), but not all (Grace et al., 1995b) Amazonian forest sites. The method we have used here is not, of course, error free. Specifically, the validity of the regional estimates presented here are dependent on three things. Firstly (1), the region studied must be horizontally homogenous at scales larger than those smoothed out by the daytime ABL turbulence (Raupach and Finnigan, 1995). Second (2), the Eulerian approach makes it necessary to take into account any possible advective fluxes both above and within the ABL. Third (3), any vertical movement of air in the period between the two flights forming the basis of the calculation must be considered.

(1) The "mixing" time within the daytime (convective) ABL can be taken as about $4 h / w^{*}$, where $w^{*}$ is the convective velocity scale (Raupach and Finnegan, 1995). For the morning flights $h$ was typically $800 \mathrm{~m}$ and $w^{*} \sim 1.5 \mathrm{~s}^{-1}$ with the horizontal wind velocity in the mixed layer around $2 \mathrm{~m} \mathrm{~s}^{-1}$. Thus the air being sampled in any one morning flight represented the trajectory $3 \mathrm{~km}$ upwind with an averaging area around $7 \mathrm{~km}^{2}$. The scale of heterogeneity immediately around the towers would have been much less, being limited to topographic variations of a length scale typically around $0.5 \mathrm{~km}$ (Araújo et al., 2002). So surface heterogeneities immediately around the point of measurement were small and any flux variations associated with them should have been blended out within the ABL. For both the 10:30 h and 16:40 $\mathrm{h}$ measurements the air sampled would have been regionally representative.

(2) Our trajectory analysis shows little evidence of changes in the direction of the mean lateral flow throughout the experiment and especially between any two flights, which we interpret as a likely absence of any significant advective effects confounding our results (Fig. 1 and supplementary information http://www.biogeosciences.net/4/759/ 2007/bg-4-759-2007-supplement.pdf). This is also consistent with the near constant $\mathrm{CO}_{2}$ mole fractions measured above the ABL (mean \pm standard deviation = 
$365.3 \pm 0.6 \mu \mathrm{mol} \mathrm{mol}^{-1}$ : overall $2000-3000 \mathrm{~m}$ column averages for the 14 measurement flights from 7-21 July) and the absence of any strong convective activity during the early dry season. Although sometimes close, our trajectory analysis showed that there was no evidence of air having passed over the nearby city of Manaus, over areas of large-scale deforestation, or over extended areas of open water in rivers or lakes. Thus, we can be reasonably confident that our estimates have not been significantly biased by advective effects. In particular, there is no reason to suspect there may have been a systematic bias between the night-time and day-time integration periods.

(3) Even small vertical velocities can affect regional flux estimates (Raupach and Finnigan, 1995; Lloyd et al., 1996; Laubach and Fritsch, 2002). Here we have tried to account for this effect utilizing the NCEP/NCAR reanalysis output (Kalnay et al., 1996). Although we accept that these modelderived estimates are far from ideal, it is hard to envision how systematic day-night differences could occur. Thus, we believe our main conclusions to be robust.

Lloyd et al. (2001) and Cleugh et al. (2004) provided detailed discussions of errors associated with the ABL budgeting technique. Although similar detailed sensitivity analyses have not been undertaken here, we did assess the relative sensitivity of the calculated fluxes to variations in the $w_{\text {top }}$ term as this is typically being the parameter which is least well known (coming from global model outputs) and so, correspondingly, imparts the greatest errors upon the calculated fluxes (Lloyd et al., 2001). As measurements were typically made under high pressure cell conditions, the $w_{\text {top }}$ term was usually negative, and we found that an assumed error in the estimate used of $\pm 50 \%$ resulted in the estimated fluxes varying by about $\pm 15 \%$. Overall, uncertainties in estimated surface fluxes of between 20 and $30 \%$ can be considered typical for scalars such as $\mathrm{CO}_{2}$ using ABL budgeting methods and when measurements are made under fair-sky conditions and in the absence of appreciable advection (Lloyd et al., 2001; Cleugh et al., 2004), as was the case here.

It has long been known that lower than expected ecosystem carbon dioxide efflux rates may be measured by the eddy covariance techniques on calm nights, even when changes in the amount of $\mathrm{CO}_{2}$ stored within the canopy space are taken into account (Goulden et al., 1996). And estimated daily carbon balances can be drastically altered depending on the apparent turbulence threshold used, especially for tropical forests (Miller et al., 2004). Nevertheless, accounting for this effect is not straightforward (Ometto et al., 2005) and the logic behind applying such corrections is not always clear (e.g. Saleska et al., 2003). Indeed, even though lower rates of $\mathrm{CO}_{2}$ efflux may be measured by eddy covariance systems on calm nights, it has also been shown that 24-h integrals of the net surface $\mathrm{CO}_{2}$ flux may be independent of the night time turbulence regime, at least for one of the Manaus towers considered as part of this study (Kruijt et al., 2004). In such a situation, corrections for night-time flux measurements might not be appropriate and it should not automatically be concluded that an underestimation of night time fluxes by the Manaus eddy covariance towers accounts for the differences in Fig. 4.

Independent estimates of both 24-h and night-time/daytime fluxes, using the ABL technique used here, even though of limited duration and of an unknown accuracy, provide important additional information on the reliability of tower based eddy covariance measurements. It seems likely that horizontal drainage of $\mathrm{CO}_{2}$ away from the measurement towers at night is, at least part, the reason for the inference of erroneously high rates of $\mathrm{CO}_{2}$ accumulation (Goulden et al. 2006; Araújo et al., 2007). This "missing" $\mathrm{CO}_{2}$, which is not detected by the eddy covariance method, is, however, measured by the ABL budgeting method in association with early morning advective fluxes associated with the onset of surface warming.

A significant underestimation of night time fluxes from the Manaus eddy covariance towers was also inferred from measurements of $\mathrm{CO}_{2}$ profiles within the nocturnal boundary layer (NBL) in the same area as studied here in 1995, where integrated eddy correlation measurements were found to infer a substantially larger net carbon sink than was calculated using nighttime respiration rates derived from NBL profiles (Culf et al., 1999). Further support for this underestimation of night time fluxes also comes from recent work examining ecosystem respiration rates for the Manaus "K34" tower where, except for nights of sustained high turbulence, soil, stem and leaf chamber measurements suggested substantially higher ecosystem respiration rates than obtained from concurrent micrometeorological measurements (Chambers et al., 2004). Furthermore, Lagrangian dispersion inversion studies of Simon et al. (2005) at the Manaus K34 tower during LBACLAIRE also suggested quite similar night-time $\mathrm{CO}_{2}$ fluxes as the ABL method. This provides additional evidence that the eddy covariance system did not measure all fluxes leaving the soil and canopy at night.

In addition to the likely underestimation of ecosystem $\mathrm{CO}_{2}$ efflux rates at night by the EC technique, discrepancies between the two methods could also arise if there was a substantial transport of carbon from the forest to rivers (Richey et al., 2002) or from a tendency to place towers only over areas of forest slowly recovering from past disturbances (Saleska et al., 2003). These explanations are, of course, not mutually exclusive and Chou et al. (2002) interpreted both the overall magnitude and the diurnal pattern of their $\mathrm{CO}_{2}$ balance calculations (from a reanalysis of historical aircraft measurements over the Amazon) as suggesting a significant influence of net $\mathrm{CO}_{2}$ emissions from wetlands, rivers and inundated forest.

Although the results here also indicate a close to zero carbon balance for this region of central Amazonia in July (Fig. 6) we also point out that a modest carbon sink of about $1 \mathrm{t} \mathrm{C} \mathrm{ha} \mathrm{C}^{-1} \mathrm{a}^{-1}$ equates to a net carbon flux of only $0.3 \mu \mathrm{mol} \mathrm{m}^{-2} \mathrm{~s}^{-1}$. From Fig. 4 and Fig. 6 it is clear that, 
as opposed to Chou et al. (2002), we cannot claim to derive a regional $\mathrm{CO}_{2}$ budget to such a degree of accuracy. It is important to emphasize then that, although excluding a very large carbon sink as has been sometimes inferred by eddy covariance measurements, our results in no way contradict a small but significant increase in Amazon forest biomass occurring at the current time, especially in the more fertile western portions of the Basin (Baker et al., 2004).

It is also possible that some of the differences between the ABL and eddy covariance flux measurements in this study were consequence of the much larger surface coverage from the ABL budget, also including significant areas of previously disturbed forest, which are currently acting as net $\mathrm{CO}_{2}$ sources. This hypothesis was specifically presented by Saleska et al. (2003) who, working in a recently disturbed forest (Keller and Crill, 2000) observed it to be a modest source of $\mathrm{CO}_{2}$ to the atmosphere. Nevertheless, if such forests were to have been widespread in our study area then, if anything, the discrepancy between the ABL and eddy covariance flux methods should have been greater during the day than during the night. This is because a significant proportion of the high respiration rates in such forests comes from the substantial coarse woody debris present (Rice et al., 2004), and these components of the ecosystem should be substantially warmer and hence with higher respiration rates during day time periods. This is the opposite of what was observed.

\section{Conclusions}

Using aircraft measurements made under near-ideal conditions of a constant easterly wind flowing across large stretches of Amazonian rain forest before measurement, and in the absence of any appreciable convective activity, estimates of regional surface fluxes using ABL budgeting techniques suggested a close to neutral Amazon carbon balance. These results contrasted significantly to a sink inferred from measurements on the two eddy covariance towers operating in the same region and at the same time. The greatest discrepancy between the two techniques was for measurements incorporating the night-time period. This suggests a systematic underestimation of fluxes by the two eddy covariance towers at night.

Although the results here suggest that the results of some eddy covariance studies may have lead to an overestimation of the Amazonian carbon sink (Malhi and Grace, 2000), we emphasize that the results here by no means exclude a modest Amazon sink of ca. $1 \mathrm{GtCa}^{-1}$ as is suggested by some eddy covariance studies without night-time flux measurement problems (Grace et al. 1995a, b, 1996), studies on the rate of above ground biomass change (Phillips et al., 1998; Baker et al., 2004), theoretical considerations (Lloyd and Farquhar, 1996), modelling studies (Tian et al., 2000) and global atmospheric inversions (Roedenbeck et al., 2003).
Acknowledgements. This work was supported by the European Union funded LBA-Carboncycle project (EVK2-CT-1999-00023), the São Paulo State Fundação de Amparo à Pesquisa (FAPESP), the Brazilian Conselho Nacional de Desenvolvimento Científico e Technológica (CNPq) and the German Max-Planck-Gesellschaft. We also thank the pilots of the INPE Bandeirante aircraft for their enthusiastic and competent support throughout an intensive flying campaign.

Edited by: F. X. Meixner

\section{References}

Andreae, M. O., Almeida, S. S., Artaxo, P., Branda, O. C, Carswell, F. E., Ciccioli, P., Culf, A., Esteves, J. L., Gash, J., Grace, J., Kabat, P., Lelieveld, J., Malhi, Y., Manzi, A. O., Meixner, F. X., Nobre, A. D., Nobre, C., Lourdes Ruivo, M. A., Silva-Dias, M. A., Stefani, P., Valentini, R., von Jouanne, J., and Waterloo, M.: Biogeochemical cycling of carbon, water, energy, trace gases and aerosols in Amazonia: The LBA-EUSTACH experiments, J. Geophys. Res., 107, 8066, doi:10.1029/2001JD000524, 2002.

Araújo, A. C., Nobre, A. D., Kruijt, B., Culf. A. D., Stefani, P., Elbers, J., Dallarosa, R., Randow, C., Manzi, A. O., Valentini, R., Gash, J. H. C., and Kabat, P.: Dual long-term tower study of carbon dioxide fluxes for a central Amazonian rainforest: The Manaus LBA site, J. Geophys. Res., 107(D20), 8090, doi:10.1029/2001JD000676, 2002.

Araújo, A. C., Kruijt, B., Nobre, A. D., Dolman, A. J., Waterloo, M. J., Moors, E. J., and De Souza, J.: Noctural accumulation of $\mathrm{CO}_{2}$ underneath a tropical forest canopy along a topographical gradient, Ecol. Appl., in press, 2007.

Baker, T. R., Phillips, O. L., Malhi, Y., Almeida, S., Arroyo, L., Di Fiore, A., Killeen, T., Laurance, S. G., Laurance, W. F., Lewis, S. L., Lloyd, J., Monteagudo, A., Neill, D. A., Patiño, S., Pitman, N. C. A., Silva, N., and Vásquez Martínez, R.: Are Amazonian forest plots increasing in biomass?, Phil. Trans. Royal Soc. Lond. S, 359B, 353-365, 2004.

Carswell, F. E., Costa, A. L., Palheta, M., Malhi. Y., Meir, P. W., Costa, J. de P. R., Ruivo, M. de L., Leal, L. S. M., Costa, J. M. N., Clement, R. J., and Grace, J.: Seasonality in $\mathrm{CO}_{2}$ and $\mathrm{H}_{2} \mathrm{O}$ flux at an eastern Amazonian rainforest, J. Geophys. Res., 107(D20), 8076, doi:10.1029/2000JD000284, 2002.

Chambers, J. Q., Tribuzy, E. S., Toledo, L. C., Crispim, B. F., Higuchi, N., Santos, J., Araujo, A. C., Kruijt, B., Nobre, A. D., and Trumbore, S. E.: Respiration From A tropical forest ecosystem: Partitioning of sources and low carbon use efficiency, Ecol. Appl., 14, S72-S88, 2004.

Chou, W. W., Wofsy, S. C., Harriss, R. C., Lin, J. C., Gerbig, C., and Sachse, G. W.: Net fluxes of $\mathrm{CO}_{2}$ in Amazonia derived from aircraft observations, J. Geophys. Res., 107(D22), 4614, doi:10.1029/2001JD001295, 2002.

Cleugh, H. R., Raupach, M. R., Briggs, P. R., and Coppin, P. A.: Regional-Scale Heat and Water Vapour Fluxes in an Agricultural Landscape: An Evaluation of CBL Budget Methods at OASIS, Bound.-Lay. Meteorol., 110, 99-137, 2004.

Culf, A. D., Fisch, G., Malhi, Y., Costa, R. C., Nobre, A. D., Marques, A. D., Gash, J. H. C., and Grace, J.: Carbon dioxide measurements in the nocturnal boundary layer over Amazonian for- 
est, Hydrol. Earth Syst. Sci., 3, 39-53, 1999,

http://www.hydrol-earth-syst-sci.net/3/39/1999/.

Freitas, S. R., Dias, M. A. F. S., Dias, P. L. S., Longo, K. M., Artaxo, P., Andreae, M. O., and Fischer, H.: A convective kinematic trajectory technique for low resolution atmospheric models, J. Geophys. Res., 105, 24 375-24 386, 2000.

Goulden, M. L., Munger, J. W., Fan, S.-M., Daube, B. C., and Wofsy, S. C.: Measurements of carbon sequestration by long term eddy covariance. Methods and a critical evaluation of accuracy, Global Change Biol., 2, 169-182, 1996.

Goulden, M. L., Miller, S. D., and da Rocha, H. R.: Nocturnal cold air drainage and pooling in a tropical forest, J. Geophys. Res., 111(D8), D08S04, doi:10.1029/2005JD006037, 2006.

Grace, J., Lloyd, J., McIntyre, J., Miranda, A. C., Meir, P., Miranda, H. S., Nobre, C., Moncrie, J., Massheder, J., Malhi, Y., Wright, I., and Gash, J.: Carbon dioxide uptake by an undisturbed tropical rain forest in southwest Amazônia, 1992 to 1993, Science, 270, 778-780, 1995a.

Grace, J., Lloyd, J., McIntyre, J., Miranda, A. C., Meir, P., Miranda, H. S., Nobre, C. R., Moncrieff, J., Wright, I. R., and Gash, J. H. C.: Fluxes of carbon dioxide and water vapour over an undisturbed tropical forest in south-west Amazonia, Global Change Biol., 1, 1-12, 1995b.

Grace, J., Mali, Y., Lloyd, J., McIntyre, J., Miranda, A. C., Meir, P., and Miranda, H. S.: The use of eddy covariance to infer the net carbon dioxide uptake of Brazilian rain forest, Global Change Biol., 2, 209-217, 1996.

Kalnay, E., Kanamitsu, M., Kistler, R., Collins, W., Deaven, D., Gandin, L., Iredell, M., Saha, S., White, G., Woollen, J., Zhu, Y., Chelliah, M., Ebisuzaki, W., Higgins, W., Janowiak, J., Mo, K. C., Ropelewski, C., Wang, J., Leetmaa, A., Reynolds, R., Jenne, R., and Joseph, D.: The NCEP/NCAR 40-year reanalysis project, Bull. Am. Meteor. Soc., 77, 437-47, 1996.

Keller, M. and Crill, P.: Site Scouting and Selection for the Tapajós National Forest and Santarém/ Belterra, Pará. (unpublished report http://lba.cptec.inpe.br/lba/eng/research/santarem report/santarem2.html, 2000.

Kruijt, B., Elbers J. A., von Randow, C., Araújo, A. C., Oliveira, P. J., Culf, A., Manzi, A. O., Nobre, A. D., Kabat, P., and Moors, E. J.: The robustness in eddy correlation fluxes for Amazon rainforest conditions, Ecol. Appl., 14, S101-S113, 2004.

Kruijt, B., Lloyd, J., Grace, J., McIntyre, J. A., Farquhar, G. D., Miranda, A. C., and McCracken, P.: Sources and sinks of $\mathrm{CO}_{2}$ in Rondonia tropical rain forest, in: Amazonian Deforestation and Climate, Gash, J. H. C., Nobre, C. A., Roberts, J. M., and Victoria, R. L., Wiley. Chichester, 1996.

Laubach, J. and Fritsch, H.: Convective boundary layer budgets derived from aircraft data, Agr. Forest Meteorol., 111, 237-263, 2002.

Lloyd, J.: The $\mathrm{CO}_{2}$ dependence of photosynthesis, plant growth responses to elevated $\mathrm{CO}_{2}$ concentrations and their interactions with soil nutrient status II. Temperate and boreal forest productivity and the combined effects of increasing $\mathrm{CO}_{2}$ concentrations and increased nitrogen deposition at a global scale, Functional Ecology, 13, 439-459, 1999.

Lloyd, J. and Farquhar, G. D.: The $\mathrm{CO}_{2}$ dependence of photosynthesis, plant growth responses to elevated atmospheric $\mathrm{CO} 2$ concentrations and their interaction with plant nutrient status, Functional Ecology, 10, 4-32, 1996.
Lloyd, J., Kruijt, B., Hollinger, D. Y., Grace, J., Francey, R. J., Wong, S.-C., Kelliher, F. M., Miranda, A. C., Farquhar, G. D., Gash, J. H. C., Vygodskaya, N. N., Wright, I. R., Miranda, H. S., and Schulze, E.-D.: Vegetation effects on the isotopic composition of atmospheric $\mathrm{CO}_{2}$ as local and regional scales: Theoretical aspects and a comparison between rainforest in Amazonia and a boreal forest in Siberia, Aust. J. Plant Physiol., 23, 371-399, 1996.

Lloyd, J., Francey, R. J., Mollicone, D., Raupach, M. R., Sogochev, A., Arneth, A., Byers, J. N., Kelliher, F. M., Rebmann, C., Valentini, R., Wong, S.-C., Bauer, G., and Schulze, E.-D.: Vertical profiles, boundary layer budgets and regional flux estimates for $\mathrm{CO}_{2}$, its ${ }^{13} \mathrm{C} /{ }^{12} \mathrm{C}$ ratio and for water vapour above a forest/bog mosaic in central Siberia, Global Biogeochem. Cycles, 15, 267284, 2001.

Lloyd, J., Langenfelds, R. L., Francey, R. L., Gloor, M., Tchebakova, N. M., Zolothukhine, D., Brand, W. A., Werner, R. A., Jordan, A., Allison, C. A., Zrazhewske, V., Shibistova, O., and Schulze, E.-D.: A trace gas climatology above Zotino, central Siberia, Tellus, 51B, 749-767, 2002.

Malhi, Y. and Grace, J.: Tropical forests and atmospheric carbon dioxide, Trends Ecol. Evol. 15, 332-337, 2000.

Malhi, Y., Nobre, A. D., Grace, J., Kruijt, B., Pereira, M. G. P., Culf, A., and Scott, S.: Carbon dioxide transfer over a Central Amazonian rain forest, J. Geophys. Res., 103, 31 593-31 612, 1998.

Miller, S. D., Goulden, M. L., Menton, M. C., Rocha, H. R., Freitas, H. C., Figueira, A. M. S., and Sousa, C. A. D.: Biometric and micrometorological measurements of tropical forest carbon balance, Ecol. Appl., 14, S114-S126. 2004.

Ometto, J. P. H. B., Nobre, A., Rocha, H. R., Artaxo, P., and Martinelli, L. A.: Amazonia and the modern carbon cycle: lessons learned, Oecologia, 143, 483-500, doi:10.1007/s00442005-0034-3, 2005.

Phillips, O. L., Malhi, Y., Higuchi, N., Laurance, W. F., Nuñez V. P., Vásquez, M., R., Laurance, S. G., Ferriera, L. V., Stern, M., Brown, S., and Grace, J.: Changes in the carbon balance of tropical forest: evidence from long-term plots, Science, 282, 439442, 1998.

Pielke, R. A. Cotton, W. R., Walko, R. L., Tremback, C. L., Lyons, W. A., Grasso, L. D., Nicholls, M. D., Moran, M. D., Wesley, D. A, Lee, T. A., and Copeland, J. H.: A comprehensive meteorological modeling system - RAMS, Meteorol. Atmos. Phys., 49, 69-91,1992.

Raupach, M. R., Denmead, O. T., and Dunix, F. X.: Challenges in linking atmospheric $\mathrm{CO}_{2}$ concentrations to fluxes at local and regional scales, Australian Journal of Botany, 40, 697-716, 1992.

Raupach, M. R. and Finnigan, J. J.: Scale issues in boundary-layer meteorology: surface energy balances in heterogeneous terrain, Hydrol. Processes, 9, 589-612, 1995.

Rice, A. H., Pyle, E. H., Saleska, S. R., Hutyra, L., Carmargo, P. B., Portilho, K., Marques, D. F., and Wofsy, S. F.: Carbon balance and vegetation dynamics in an old-growth Amazonian forest, Ecol. Appl., 14, 855-871, 2004.

Richey, J. E., Melack, J. M., Aufdenkampe, A. K., Ballester, V. M., and Hess, L. L.: Outgassing from Amazonian rivers and wetlands as a large tropical source of atmospheric $\mathrm{CO}_{2}$, Nature, 416, 617620, 2002.

Roedenbeck, C., Howling, S., Gloor, M., and Heimann, M.: $\mathrm{CO}_{2}$ 
flux history 1982-2001 inferred from atmospheric data using a global inversion of atmospheric transport, Atmos. Chem. Phys., 3, 1914-1964, 2003,

http://www.atmos-chem-phys.net/3/1914/2003/.

Saleska S. R., Miller, S. D., Matross, D. M., Goulden, M. L., Wofsy, S. C., da Roacha, H. R., de Camargo, P. B., Crill, P., Daube, B. C., de Freitas, H. C., Hutyra, L., Keller, M., Kircho, V., Menton, M., Munger, J. W., Pyle, E. H., Rice, A. H., and Silva, H.: Carbon in Amazon forests: Unexpected seasonal fluxes and disturbanceinduced losses, Science, 302, 1554-1557, 2003.

Simon, E., Lehmann, B. E., Ammann, C., Ganzeveld, L., Rummel, U., Meixner, F.X., Nobre, A. D., Araújo, A., and Kesselmeier, J.: Lagrangian dispersion of ${ }^{222} \mathrm{Rn}, \mathrm{H} 20$ and $\mathrm{CO}_{2}$ within Amazonian rain forest, Agr. Forest Meteorol., 132, 286-304, 2005.
Tian, H., Melillo, J. M., Kicklighter, D. W., McGuire, A. D., Helfrich III, J., Moore III, B., and Vorosmarty, C. J.: Climatic and biotic controls on annual carbon storage in Amazonian ecosystems, Global Ecol Biogeogr., 9, 315-335, 2000.

Wofsy, S. C., Harris, R. C., and Kaplan, W. A.: Carbon dioxide in the atmosphere over the Amazon Basin, J. Geophys. Res., 93, 1377-1387, 1988. 